\title{
Guest Editors' Introduction to the Special Issue: Towards the Prevention of Genocide
}

\author{
Borislava Manojlovic \\ Seton Hall University \\ Tetsushi Ogata \\ University of California, Berkeley \\ Andrea Bartoli \\ Seton Hall University
}

Follow this and additional works at: https://digitalcommons.usf.edu/gsp

\section{Recommended Citation}

Manojlovic, Borislava; Ogata, Tetsushi; and Bartoli, Andrea (2016) "Guest Editors' Introduction to the Special Issue: Towards the Prevention of Genocide," Genocide Studies and Prevention: An International Journal: Vol. 9: Iss. 3: 1-3.

DOI:

http://dx.doi.org/10.5038/1911-9933.9.3.1395

Available at: https://digitalcommons.usf.edu/gsp/vol9/iss3/3

This Editorial is brought to you for free and open access by the Open Access Journals at Digital Commons @ University of South Florida. It has been accepted for inclusion in Genocide Studies and Prevention: An International Journal by an authorized editor of Digital Commons @ University of South Florida. For more information, please contact digitalcommons@usf.edu. 


\section{Guest Editors' Introduction to the Special Issue: Towards the Prevention of Genocide}

This issue offers an overview of recent developments in genocide prevention that are taking place in our international and intellectual landscapes. It is dedicated to analyzing the latest debates, trends and dynamics in an effort to appreciate a more systematic outlook of the field as well as to reflect upon more effective genocide prevention strategies. There is a need for linking knowledge of genocidal violence indicators and a proper course of action. There were two important moments when human collective consciousness reaffirmed its dedication to Never Again in the form of international consensus and commitment. First was when the UN General Assembly adopted the Convention on the Prevention and Punishment of the Crime of Genocide in 1948. The second took place in September 2005, when the UN General Assembly adopted its Outcome Document acknowledging the sovereign responsibility for protecting the populations from mass atrocity crimes. These are the two key documents that underlie any discussions on genocide prevention, as an expression of our collective human will trying to overcome our unfortunate propensity to willfully neglect our responsibility to prevent genocide. This issue starts with these two special contributions, highlighting how we are making progress in this regard by practicing and implementing the agreed upon norms.

At the nexus of knowing genocidal risks and taking proper actions, it is important to highlight the efforts by Adama Dieng, United Nations Special Adviser on the Prevention of Genocide, and Jennifer Welsh, United Nations Special Adviser on the Responsibility to Protect, who present in this issue the conceptual overview and the practical application of the Framework of Analysis for Atrocity Crimes. The original Framework was released in 2009, and the current edition is a significant contribution to our attempts to operationalize the prevention work. While the strength of this instrument will ultimately hinge on its consistent and widespread use, both in the UN systems and national governments, the close scrutiny of the Framework signals the need for consistent investment in data gathering and verification both by the national and interactional actors. The genocide prevention can be effective only if it is predicated on sharing knowledge, tools and practices in networks of actors. The recent testimony of this orientation is the growth of the Global Action Against Mass Atrocity Crimes (GAAMAC), which concluded its second successful gathering in Manila in February 2016. It is a state-led initiative to prevent mass atrocity crimes (not only the crime of genocide), serving as a platform for exchange and dissemination of learning and good practices in order to develop national strategies and mechanisms for atrocity prevention.

Another contribution comes from Ernesto Verdeja who complements the Framework by the Office of the UN Special Advisers by providing an overview of the current forecasting models that are used to predict the onset of genocide and mass killings. He surveys the increasingly sophisticated field of risk assessment and early warning practices, while evaluating how accurate they actually are, a question that is of particular interest in this issue. Prevention is deeply linked to a particular form of knowledge: politically relevant knowledge. Who is creating this knowledge? Who is making it relevant? To know accurately the early warning signs of violence in complex situations, and understand them not only early but also properly so as to employ swift and decisive measures, is a challenge Verdeja revisits. Both the risk assessment and early warning approaches are part of the prevention paradox: we can prevent only what we know and understand. His article situates discussions on the current forecasting models in terms of their applicability to actual prevention.

Essential to the understanding of any risk is the use of language and especially the highly charged formulation of words aiming at or contributing to violence. The nuances of language and its use in highly hostile environments is at the core of the paper of Susan Benesch and Jonathan Leader Maynard. While distancing themselves from an oversimplified link of hate and violence by elaborating on the "dangerousness" of the speech, their contribution enhances both the theory and practice of mass atrocity risk monitoring and prevention. They combine the two existing frameworks that they have independently formulated, offering an understanding of the contextual and content-based risk factors associated with dangerous speech and ideology.

Kjell Anderson and Ingjerd Brakstad analyze the role of the media in shaping discourse around mass atrocities. Their discussions are underpinned by an overarching question that is deeply

Borislava Manojlovic, Tetsushi Ogata and Andrea Bartoli, "Guest Editors' Introduction to the Special Issue: Towards the Prevention of Genocide" Genocide Studies and Prevention 9, 3 (2016): 1-3. @2016 Genocide Studies and Prevention.

http://dx.doi.org/10.5038/1911-9933.9.3.1395 
ethical-how can people be bystanders to atrocities happening in distant places and how can they exercise their responsibility to act and help their fellow human beings. They argue that the media, in some cases, encourages passivity in response to mass atrocities, providing justifications for inaction. They also tackle the important topic of how people tend to engage with distant suffering in superficial ways when it is perceived as inevitable, alien, and outside of their control.

Bridget Moix examines recent research and evolving practice of community-based approaches to preventing and mitigating mass violence. Local communities need to be supported as key agents in prevention of mass violence as they are an alternative to the external, military interventions that only create a fertile ground for long term grievances and renewed cycles of violence. Moix argues for conflict-resilient local actors and drawing the attention of the policymakers to make the shift towards a more constructive context-specific approach to genocide prevention.

Timothy Williams points to the need for a proper knowledge-action nexus through a Qualitative Comparative Analysis (QCA) of the 40 genocide cases and 100 non-genocidal incidents which occurred between 1955 and 1998. This approach builds on data from the Political Instability Task Force's State Failure Problem Set, a seminal contribution to the field led by Barbara Harff. QCA is a method for capturing the "configurations of conditions" leading to the occurrence and nonoccurrence of the outcome, thereby highlighting that there are some combinations of conditions that are more pertinent to genocide occurrence. QCA can systematically analyze interactions among the conditions - not just conditions individually - and therefore it can potentially provide us with a framework of identifying more genocidal combinations of conditions.

Similarly, James Snow's article moves away from the essentialist framing of genocide, but more toward identifying the affinities of complex genocide phenomena. He does this from the epistemological angle, recasting, yet again, the definitional debates on what constitutes genocide in the field of genocide prevention. Snow argues that the original definition of genocide, as coined by Raphael Lemkin, along with its criticisms and calls for another definition, share an all-toofamiliar presumption about what a definition should be, going as far back as Socrates and Plato. According to the Socratic conception, people share an orientation that seeks an essential form, a general template, of the things they define, reducing their complexity to a "general idea." However, Ludwig Wittgenstein's notion of family resemblances provides an alternative, and perhaps more effective-for prevention purposes - way of looking at genocide by highlighting patterns of similarities of genocidal acts and events as described by the language users. Such crisscrossing analysis of patterns of intent by perpetrators of mass atrocities can be conducive to understanding and acting on new shapes and forms of genocidal violence today and beyond.

Sharing this pattern-based inquiry into the causation of genocidal violence, Stephen McLoughlin and Maartje Weerdesteijn analyze Zambia and Zimbabwe, where similarities abound, and yet, one case resulted in mass atrocities while the other did not. Their article aptly contributes to the overarching theme of knowing properly and effectively, in terms of the role of leadership in setting the stage for violence or peaceful coexistence. It is also a contribution to the critical examination of risk factors from the agentic perspective. While it is important to remind us that no condition alone-even the decisive role of leaders - is capable of causing genocide, there is a dimension of humans choosing that makes genocide conceivable and actual. The cases of Zambia and Zimbabwe point to the need of disaggregating the pattern of behavioral and strategic choices made by leaders, within similar structural risk factors involved. Conversely speaking, leadership is needed at multiple levels to secure the emergence of a genocide prevention system that will be inclusive and effective, and therefore the Zambian style of leadership is worth noting.

Matthew Levinger contributes through an in-depth analysis of the Rwandan case and buttresses the need of a cognitive frame that can see not only a set of destructive risk factors, but also a pattern of their destructive interactions. Levinger's analysis challenges our own cognitive framework between knowing, understanding, and acting and provides a far reaching implication to other cases such as Libya, South Sudan, and Syria, with prescriptions for action for decision makers and policy makers.

It is essential to see the task of genocide prevention as a collaborative effort, a learning and practice-oriented investment that uncovers trends, patterns, and dynamics of genocide with a view to taking concrete and decisive action when such risks emerge. Prevention of any form of 
systematic violence is not only the responsibility of political actors, but also of all those faced with the challenges of human coexistence. No state and no human group are immune from genocidal violence. Warnings make sense to those who are interested in heeding them. Prevention is predicated on the process of knowing - the capacities for inquiry and verification of such knowledge-and this process must be more inclusive and transparent so that we can make more robust linkages between what we know and which action to take. These movements are political in nature and can be accomplished by legitimate, credible processes that involve academic, political, and diplomatic engagement. We hope that this special issue is a step in that direction.

Lastly, we would like to acknowledge Laurel Stone and Thomas Hill who helped us with coordination and administrative aspects of the special issue. Also, the special issue would not be possible without the help, support and keen attention to detail from Christian Gudehus, Editor-inChief of the Genocide Studies and Prevention: An International Journal.

Borislava Manojlovic Tetsushi Ogata Andrea Bartoli 